\title{
Indonesia Black Cumin (Nigella sativa L.) Seeds Extract as Ameliorant Reproductive Function in Type-2 Diabetes Mellitus
}

\author{
RETNO SUSILOWATI ${ }^{1 *}$, NAILIRROHMAH HIDAYATIN ${ }^{1}$, AMALIA RIZKA DIANA ${ }^{1}$, \\ TRI KUSTONO ADI ${ }^{2}$ \\ ${ }^{1}$ Department of Biology, Faculty of Science and Technology, \\ Universitas Islam Negeri Maulana Malik Ibrahim Malang \\ Jl. Gajayana No. 50, Malang, East Java, Indonesia. 65144 \\ *Email: retnosusilowati@bio.uin-malang.ac.id \\ ${ }^{2}$ Graduate School of Science, Hiroshima University \\ 1-3-1 Kagamiyama, Higashi-Hiroshima City Hiroshima, Japan. 739-8526
}

Received 4 January 2020; Received in revised form 29 April 2020; Accepted 17 May 2020; Available online 30 June 2020

\begin{abstract}
Diabetes initiates augmented damage in levels of nuclear and mitochondrial DNA in males. As a result, the sperm DNA is affected, leading to lower levels of fecundity and influencing reproductive health. This study aims to improve male reproductive function and oxidative stress status in diabetic rats. Combination High Fat Diet (HFD) and Streptozotocin (STZ) injection $30 \mathrm{mg} / \mathrm{kg}$ intraperitoneally are the initiations of DM-2 for 14 weeks. Treat therapy using $80 \%$ ethanol extract of black cumin seeds takes five weeks. Based on parametric test on ANOVA test results followed by Duncan Multiple Range Tests on the concentration, abnormalities of spermatozoa and Super Oxide Dismutase (SOD) effects and the KruskalWallis test followed by the Mann-Whitney test on non-parametric data of the spermatozoa motility and Malondialdehyde (MDA) levels, showed that obtaining black cumin dose 48 is an effective dose in improving sperm quality and stress oxidation level. It has the same effect with metformin, even has MDA level less than normal rats. This study finds out Ns-48 is an effective dose of ethanol extract of black cumin seeds to improving spermatozoa quality and stress oxidation level, so that it becomes valuable information for research related to the improvement of reproductive function in diabetes mellitus disease.
\end{abstract}

Keywords: diabetes; MDA; reproduction; spermatozoa; SOD

\section{INTRODUCTION}

Diabetes mellitus type 2 (DM-2) is one category of metabolic disorder characterized by increased blood glucose levels, and the body's cells are insulin impervious. Globally, the total of people with DM-2 continues to grow, 382 million people in 2013, 425 million in 2017, so that the assessed number of people travail from DM-2 is 592 million in 2035, about 629 million in 2045 (Saeedi et al., 2019). Type 1 and type 2 diabetes are the two main types, with type 2 diabetes widely held (> 85\%) of total diabetes prevalence. Prevalence will surge in all countries, but the highest decay will be experienced in low-income countries (Forouhi \& Wareham, 2014; Cho et al., 2018).

DM-2 sufferers are easy to experience oxidation stress and hypogonadism (Asmat et al., 2016; Dhindsa et al., 2018). The interaction of glucose with proteins leads to an amadori product and then advanced glycation endproducts (AGEs). These AGEs, via their receptors (RAGEs), activate enzymes and alterations in their structures and functions. Moreover, AGEs cause diabetes hitches (Singh et al., 2014). Radical Oxygen Species (ROS) and AGEs are mediators of diabetes worries (Matough et al., 2014; Omolaoye \& Du Plessis, 2018), such as a coronary arterial disorder (Fishman et al., 2018), diabetic neuropathy and gloominess (Réus et al., 2019), diabetic retinopathy (Solomon et al., 2017), and interference of the structure-function of reproductive organs both women and men, thus it becomes diabetic barrenness (Bansal \& Bilaspuri, 2011; Morrison \& Brannigan, 2015). Diabetes mellitus causes increased damage in levels of nuclear DNA (sperm nuclear) and mitochondrial DNA in males (Basmatzou \& Hatziveis, 2016; Pourmasumi et al., 2017; Laleethambika et al., 2019).

DM-2 generally performs aged 30 years, but currently, the disease also outbreaks someone aged 20 years. This age is an early 
stage of reproduction, a period where the eminence of spermatozoa and ovum that are good is needed to produce offspring. Thus, efforts are needed to overcome reproductive failure caused by DM-2.

Distinctly, $N$. sativa has been studied as an antidiabetic, maintainer of reproductive wellbeing, and a source of antioxidants. Ethanol extracts $N$. sativa at dose 200 and 400 $\mathrm{mg} / \mathrm{kg}$ body weight could decrease MDA levels in STZ-induced hippocampus mice (Abbasnezhad et al., 2015). As an antidiabetic, inquiry shows the usage of $N$. sativa in patients and investigational animals. Feeding of $N$. sativa at a dose of $2 \mathrm{~g} /$ day set off a significant lessening in FBG, 2hPG, and $\mathrm{HbA} 1 \mathrm{c}$ without generous changes in body weight, reduced insulin resistance, and developed pancreatic beta-cell function (Bamosa et al., 2010).

Utilization of seeds $N$. sativa in prosperous the reproductive status of male animals has also been carried out. Compared to the healthy reproductive organs of rats, the ethanol extract $N$. sativa at a dose of $400 \mathrm{mg} / \mathrm{kg}$ does not affect to the weight of male reproductive organs and reproductive cells but can significantly increase testicles and epididymis weight (Parandin et al., 2012).

Based on previous research, it was shown that the study and utilization of $N$. sativa both in the form of seed powder and oil were more as antidiabetic and as maintainers of reproductive health than compared to diabetic infertility. This study aims to evaluate the effect of extract $N$. sativa seeds on sperm content, viability, motility, sperm morphology abnormalities, and their impact on SOD and MDA levels in DM-2.

\section{MATERIALS AND METHODS}

Nigella sativa Seeds Extract Preparation. Indonesian N. sativa seeds samples were $120 \mathrm{~g}$ obtained from Balitro, Bogor. N. sativa seeds dried handling an oven that is $\pm 40^{\circ} \mathrm{C}$ for $2 \times 24$ hours, so it becomes dry, then ground until smooth and sifted with 60 mesh sieves. Extraction commences with a maceration process with $80 \%$ ethanol. Every $60 \mathrm{~g}$ of $N$. sativa seeds powder soaked using $300 \mathrm{ml}$ of $80 \%$ ethanol solvent for 24 hours and stirred using a shaker for 3 hours. Then it was filtered. The filtrate extra ${ }^{\circ} t$ obtained was concentrated with a rotary evaporator at $40^{\circ} \mathrm{C}, 70 \mathrm{rpm}$ to become concentrated extract (Bahrin et al., 2018), obtained are $23.57 \mathrm{~g}(39.28 \%)$.

DM-2 Animal Induction. Twenty-four rats were divided erratically into one regular group (non-diabetic) and five diabetic groups. Each group has four replication. All rats acclimatize for two weeks. After passing through the adaptation period, each rat except in the standard a control group was given a high-fat diet and taken ad-libitum for nine weeks. Test animals excluding negative controls were injected with STZ intraperitoneally with a low dose of $30 \mathrm{mg} / \mathrm{kg}$ bw on the first day of the $10^{\text {th }}$ and $11^{\text {th }}$ week when administering a high-fat diet. After five days of STZ administrations, a blood glucose tolerance test was conducted to prove the success of making entries animals in the DM-2 models. The animals were alleged to have DM2 if blood glucose was $>200 \mathrm{mg} / \mathrm{dl}$ (Qinna \& Badwan, 2015).

Grouping and Treatment. Into the bargain to the normal non-diabetic group (Normal), 20 diabetic rats were separated into 5 groups, 4 replication: dose $0 \mathrm{mg} / \mathrm{kg}$ bw, 24 $\mathrm{mg} / \mathrm{kg}$ bw, $48 \mathrm{mg} / \mathrm{kg}$ bw, $72 \mathrm{mg} / \mathrm{kg}$ bw, and metformin as positive controls, successively coded as Ns-0, Ns-24, Ns-48, Ns-72, Metf. The remedy was given orally using gavage needles with a volume of $2.5 \mathrm{ml}$; treatment gave for four weeks. At the end of the examinations, rats were anesthetized and dissected for their reproductive organs. The cauda epididymis and sperm quality were observed, including concentration, viability, sperm abnormalities, and motility. The liver isolated for lysate preparation for measurement of SOD and MDA levels. The liver lysate was prepared from $0.1 \mathrm{~g}$ of the liver with diluent $1 \mathrm{ml} 0.9 \% \mathrm{NaCl}$ and centrifuged at $8000 \mathrm{rpm}$ for 20 minutes (Aulanni'am et al., 2011).

Data Retrieval. 1) The measurement of sperm concentration was carried out using a Neubauer improved cell counting chamber. Sperm is gained from the epididymis duct and diluted with $0.9 \% \mathrm{NaCl}$ solution, with a dilution factor of 200X. Preparations were noted and 
calculated using a microscope with 400X magnification. Sperm concentration data state the number of sperm cells $/ \mathrm{ml}$; 2) Sperm motility was calculated using the Neubauer improved cell counting chamber. Sperm is acquired from the epididymis duct and diluted with $0.9 \% \mathrm{NaCl}$ solution with a dilution factor of 200X. The progressive motility of sperm (frontal motion) was perceived and calculated using a microscope with $400 \mathrm{X}$ magnification. Sperm motility data states the percentage of sperm cells with a progressive movement from 100 sperm cells found; 3 ) The viability of sperm examines at $50 \mu \mathrm{l}$ of sperm in glass objects with eosin-nigrosin staining. Examine used microscope at a magnification of $400 \mathrm{X}$. The dead sperm is indicated by sperm head stained, while the lives sperm head is not colored. Viability data stated live-cell percentages of several sperms observed (100 sperm cells); 4) A sperm abnormality notices by calculating sperm morphological abnormalities (compared to typical sperm forms) using eosin negrosin staining. Examinations were carried out using a microscope with 400X magnification. Inconsistencies of data state the percentage of sperm cells that experience morphological abnormalities of several sperms observed (100 sperm cells); 5) The liver method's measurement was provided by the MDA determination kit from Sigma Aldrich in which the wavelength setting was $\lambda 532 \mathrm{~nm}$. As much as $100 \mu \mathrm{L}$ of liver lysate comprised in the new microtube, added $550 \mu \mathrm{L}$ of aquadest, $100 \mu \mathrm{l}$ of $10 \%$ TCA, $250 \mu \mathrm{l}$ of $\mathrm{HCl} 1 \mathrm{~N}$, and $100 \mu \mathrm{l} \mathrm{Na}-$ Thio $1 \%$. After that, it was separate out and centrifuged at $500 \mathrm{rpm}$ for 10 minutes. The supernatant was transported to a microtube and soaked in a water bath at $100^{\circ} \mathrm{C}$ for 30 minutes. The supernatant cooled at room temperature 26$27^{\circ} \mathrm{C}$, then measured the absorbance using a spectrophotometer. MDA levels were obtained by calculating the absorbance value into a standard curve linear equation; 6) The SOD activity measurement was carried out using nitroblue tetrazolium (NBT) under the SOD determination kit (from Merck) procedure in which the wavelength setting was $\lambda 440 \mathrm{~nm}$. A total of $400 \mu \mathrm{l}$ of cold ethanol solution $37.5 / 62.5(\mathrm{v} / \mathrm{v})$ was added to the $150 \mu 1$ of liver lysate. Then vortex splitting is constantly for 3 seconds and centrifuged at a speed of $4400 \mathrm{rpm}$ at $4{ }^{\circ} \mathrm{C}$ for 10 minutes. $2.9 \mathrm{ml}$ of solution $\mathrm{A}$ (mixtures of xanthine solution and cytochrome c solution) was added $50 \mu 1$ of ordinary solution (control) or sample and followed by the vortex. Then add $50 \mathrm{~mL}$ of solution B (xanthine oxidase) and then slowly vortex. SOD levels were experiential using the spectrophotometer absorbance. The SOD level is achieved by calculating the absorbance value into the standard curve linear equation.

Data Analysis. Data on concentration, viability, sperm abnormalities, and MDA levels followed a normal distribution with homogeneous variants. Testing the effect of treatment was analyzed by one way ANOVA. The treatment was carried out using the Duncan Multiple Range Test (DMRT) test. Motility and SOD data have homogeneous variants but are not normally distributed, analyzed by nonparametric using the Kruskal-Wallis test followed by the Mann-Whitney test.

\section{RESULT AND DISCUSSION}

The statistical test results using ANOVA with a significance level of $5 \%$ showed a significant effect of $80 \%$ ethanol extract of $N$. sativa seeds on sperm concentration, abnormality, viability, and SOD. The KruskalWallis test results on motility sperm and MDA also showed the same results as the ANOVA test (Table 1).

Table 1. The analysis results of sperm quality and stress oxidation status in the liver of experimental rats

\begin{tabular}{|c|c|c|c|c|c|c|c|}
\hline \multirow{2}{*}{ Parameters } & \multicolumn{6}{|c|}{ Treatments } & \multirow{2}{*}{ ANOVA } \\
\hline & Normal & Ns-0 & Ns-24 & Ns-48 & Ns-72 & Metf & \\
\hline \multicolumn{8}{|l|}{ Sperm quality } \\
\hline $\begin{array}{l}\text { Concentration } \\
\left(10^{7} / \mathrm{ml}\right)\end{array}$ & $20.00 \pm 3.92^{\mathrm{d}}$ & $7.75 \pm 1.26^{\mathrm{a}}$ & $\begin{array}{l}13.50 \pm \\
3.11^{\mathrm{bc}}\end{array}$ & $\begin{array}{l}18.25 \pm \\
4.65^{\mathrm{cd}}\end{array}$ & $\begin{array}{l}11.25 \pm \\
3.78^{\mathrm{ab}}\end{array}$ & $\begin{array}{l}15.25 \pm \\
3.10^{\text {bcd }}\end{array}$ & $\mathrm{P}<0.05$ \\
\hline Viability (\%) & $71.25 \pm 2.22^{c}$ & $\begin{array}{l}47.25 \pm \\
2.22^{\mathrm{a}}\end{array}$ & $\begin{array}{l}67.75 \pm \\
3.86^{\mathrm{bc}}\end{array}$ & $\begin{array}{l}68.50 \pm \\
2.65^{\mathrm{bc}}\end{array}$ & $\begin{array}{l}63.75 \pm \\
2.99^{\mathrm{b}}\end{array}$ & $\begin{array}{l}66.50 \pm \\
4.04^{\mathrm{bc}}\end{array}$ & $\mathrm{P}<0.05$ \\
\hline
\end{tabular}




\begin{tabular}{llllllll}
\hline $\begin{array}{l}\text { Abnormality } \\
(\%)\end{array}$ & \multirow{2}{*}{$11.00 \pm 1.83^{\mathrm{a}}$} & $\begin{array}{l}21.25 \pm \\
2.22^{\mathrm{d}}\end{array}$ & $\begin{array}{l}18.00 \pm \\
1.63^{\mathrm{c}}\end{array}$ & $\begin{array}{l}14.25 \pm \\
1.71^{\mathrm{b}}\end{array}$ & $\begin{array}{l}19.00 \pm \\
2.16^{\mathrm{cd}}\end{array}$ & $\begin{array}{l}16.25 \pm \\
1.50^{\mathrm{bc}}\end{array}$ & $\mathrm{P}<0.05$ \\
\hline \multirow{2}{*}{ Motility $^{\ddagger}$} & \multirow{2}{*}{$61.53 \pm 2.83^{\mathrm{c}}$} & $\begin{array}{l}42.36 \pm \\
6.05^{\mathrm{a}}\end{array}$ & $\begin{array}{l}53.65 \pm \\
3.46^{\mathrm{b}}\end{array}$ & $\begin{array}{l}57.95 \pm \\
5.16^{\mathrm{bc}}\end{array}$ & $\begin{array}{l}51.78 \pm \\
3.55^{\mathrm{b}}\end{array}$ & $\begin{array}{l}54.10 \pm \\
1.19^{\mathrm{b}}\end{array}$ & $\mathrm{P}<0.05^{\S}$ \\
\hline Liver & & & & & & & \\
\hline SOD $(\mathrm{U} / \mathrm{ml})$ & \multirow{2}{*}{$7.30 \pm 0.62^{\mathrm{b}}$} & $3.57 \pm 0.82^{\mathrm{a}}$ & $\begin{array}{l}6.21 \pm \\
0.80^{\mathrm{b}}\end{array}$ & $\begin{array}{l}6.69 \pm \\
1.48^{\mathrm{b}}\end{array}$ & $\begin{array}{l}6.03 \pm \\
1.46^{\mathrm{b}}\end{array}$ & $7.12 \pm 1.26^{\mathrm{b}}$ & $\mathrm{P}<0.05$ \\
\hline $\mathrm{MDA}^{\ddagger}(\mathrm{ng} / \mathrm{ml})$ & $1266.50 \pm$ & $1389.63 \pm$ & $840.25 \pm$ & $773.38 \pm$ & $846.50 \pm$ & $832.75 \pm$ & \multirow{2}{*}{$\mathrm{P}<0.05^{\S}$} \\
& $30.97^{\mathrm{b}}$ & $71.49^{\mathrm{c}}$ & $321.23^{\mathrm{a}}$ & $274.75^{\mathrm{a}}$ & $326.42^{\mathrm{a}}$ & $313.02^{\mathrm{a}}$ &
\end{tabular}

Note: Normal: normal rats, non-diabetic dyslipidemia; Ns-0: diabetic rats without extract and medicine; Ns-24: Diabetic rats treated at extracts dose of $24 \mathrm{mg} / \mathrm{kgbw}$; Ns-48: diabetic rats treated at extracts dose of $48 \mathrm{mg} / \mathrm{kgbw}$; Ns-72: diabetic rats treated at dose extract of $72 \mathrm{mg} / \mathrm{kgbw}$; Metf: diabetic rats treated at metformin dose $3.6 \mathrm{mg} / \mathrm{kgbw}$; the means followed by the different alphabets in the same line shows the significant differences in DMRT test with $\dot{\alpha}=0.05 ;{ }^{\S}$ significance in Kruskal-Wallis; $\neq$ means which are followed by the different alphabet in the same line indicating the significant difference in the Mann-Whitney test.

The results of the DMRT presented that $N$. sativa extract could build up the sperm concentration of diabetic rats from all treatment groups. All handling groups are not significantly different from the positive control group metformin, but still not the same as the standard control group. This study's results are in line with the findings of Parandin et al. (2012) that $N$. sativa ethanol extract can increase sperm count, epididymal sperm reserve (ESR), and daily sperm production (DSP). This effect is possible because of the increase in ROS is a mediator of impairment to DNA integrity in the sperm nucleus, which leads to cell death, thereby reducing the concentration of spermatozoa (Bashandy, 2007).

The DMRTs showed that $N$. sativa extract could foster the viability and motility of sperm in diabetic rats at all treatment doses. There is no significant difference from the effect of standard drug metformin to the same as normal rats' viability. As a stimulate on increasing motility, the extract of $N$. sativa at the dose 24 and $72 \mathrm{mg} / \mathrm{kg}$ can increase the sperm motility of diabetic rats and the standard drug effects of metformin. The best treatment of dose 48 $\mathrm{mg} / \mathrm{kg}$, the motility equal to metformin, was raised to a normal level. This study's results generated better results than those of Parandin et al. (2012) who stated that 50\% N. sativa ethanol extract did not significantly upsurge sperm viability and motility of rats. The findings of Desai et al. (2015) support the findings of this study. Verify that giving seeds of $N$. sativa powder dose of $300 \mathrm{mg} / \mathrm{kg}$ bw for 45 days and the results of Parandin et al. (2012) which used ethanol extract and the two researchers succeeded increased testosterone to significant levels, increased luteinizing hormone (LH), and fertility indexes spermatozoa (Bashandy, 2007; Marbat et al., 2013; Desai et al., 2015). The hormones testosterone is the primary hormone accountable for signaling pathways in the process of spermatogenesis (Walker, 2011). LH/testosterone, and follicle-stimulating hormone (FSH) are important endocrine factors that can control testicular function (Ramaswamy \& Weinbauer, 2014).

Increasing the concentration, viability, and motility of sperm in this study because of the increase in testosterone levels due to the administration of ethanol extract of $N$. sativa. This condition causes an increase in the hormone testosterone and LH.

Regarding oxidation stress, the results of this study indicate that the ethanol extract of $N$. sativa seeds at all doses can reduce the level of oxidative stress. The results show an increase in SOD enzymatic antioxidants' levels, which inhibited the lipid peroxidation process. These antioxidants are evidenced by the decrease in MDA levels in the liver of diabetic experimental animals in line with the increase in SOD levels. These consequences are in line with the inquiry of Hasan et al. (2018) which informed that the infusion of $N$. sativa seeds equivalent to $100 \mathrm{mg} / \mathrm{kg}$ body weight/day in rats for three consecutive days instigated a reduction in oxidative stress, increasing SOD and GSH-Px in erythrocytes and decreasing MDA levels in serum. MDA reduction due to the content of 3 significant components in $N$. sativa oil can work as antioxidants, namely thymoquinone $43.46 \%$, p-cymene about 
$12.79 \%$, and carvacrol $(8.53 \%)$. Through the DPPH test compared to quercetin, carvacrol has adequate antioxidant activity (Burits \& Bucar, 2000).

The results of this study also displayed a decrease in morphological abnormalities of spermatozoa in DM-2 rats. The conduct of giving ethanol extract of seeds $N$. sativa dose $48 \mathrm{mg} / \mathrm{kg}$ bw in DM-2 rats best repressed the occurrence of sperm morphological abnormalities. This upshot is in line with the results of the study (Bashandy, 2007; Marbat et al., 2013). This diminution in sperm morphological abnormalities caused by the enhancement of the reproductive status of DM2 rats with $N$. sativa extract as an antioxidant. These data supported by Assi et al. (2016) reported that $N$. sativa decreased spermatozoa abnormality caused by free radicals.

\section{CONCLUSION}

The administration of $80 \%$ ethanol extract of Indonesia $N$. sativa seeds has an effect of plummeting oxidative stress to enable the process of spermatogenesis to run well. The accomplishment of spermatogenesis is shown by augmented concentration and decreased sperm abnormality, as well as increased sperm viability to surge sperm motility. For the clinical study using $N$. sativa seed herbs to improve diabetes infertility can use the equivalent of an effective extract dose of 48 $\mathrm{mg} / \mathrm{kg}$ bw. Conversely, for the improvement of standardized herbal medicines, clinical trials with adequate trials are still required.

\section{REFERENCES}

Abbasnezhad A, Hayatdavoudi P, Niazmand S, Mahmoudabady M. 2015. The effects of hydroalcoholic extract of Nigella sativa seed on oxidative stress in hippocampus of STZ-induced diabetic rats. Avicenna Journal of Phytomedicine. vol 5(4): 333-340. doi: 10.22038/ajp.2015.3921.

Asmat U, Abad K, Ismail K. (2016). Diabetes mellitus and oxidative stress-A concise review. Saudi Pharmaceutical Journal. vol 24(5): 547-553. doi: https://doi.org/10.1016/j.jsps.2015.03.013.

Assi MA, Hezmee MNM, Abba Y, Yusof MSM, Haron AW, Rajion MA, Al-Zuhairy MA. 2016. Prophylactic effect of Nigella sativa against lead acetate induced changes in spermiogram, reproductive hormones and gonadal histology of rats. Veterinary World. vol 9(11): 1305-1311. doi:
https://dx.doi.org/10.14202\%2Fvetworld.2016.130 5-1311.

Aulanni'am, Roosdiana A, Rahmah NL. 2011. Potensi fraksi etanol dan etil asetat rumput laut coklat (Sargassum duplicatum Bory) terhadap penurunan kadar malondialdehid dan perbaikan gambaran histologis jejunum usus halus tikus IBD (Inflammatory Bowel Disease). Veterinaria Medika. vol 4(1): 57-64.

Bahrin N, Muhammad N, Abdullah N, Talip BHA, Jusoh S, Theng SW. 2018. Effect of processing temperature on antioxidant activity of Ficus carica leaves extract. Journal of Science and Technology. vol 10(2): 99-103. doi: https://doi.org/10.30880/jst.2018.10.02.016.

Bamosa AO, Kaatabi H, Lebda FM, Al Elq AM, AlSultan A. 2010. Effect of Nigella sativa seeds on the glycemic control of patients with type 2 diabetes mellitus. Indian Journal of Physiology and Pharmacology. vol 54(4): 344-354.

Bansal AK, Bilaspuri GS. 2011. Impacts of oxidative stress and antioxidants on semen functions. Veterinary medicine International. vol 2011: 1-7. doi: https://doi.org/10.4061/2011/686137.

Bashandy AES. 2007. Effect of fixed oil of Nigella sativa on male fertility in normal and hyperlipidemic rats. International Journal of Pharmacology. vol 3(1): 27-33. doi: https://doi.org/10.3923/ijp.2007.27.33.

Basmatzou T, Hatziveis K. 2016. Diabetes mellitus and influences on human fertility. International Journal of Caring Sciences. vol 9(1): 371-379.

Burits M, Bucar F. 2000. Antioxidant activity of Nigella sativa essential oil. Phytotherapy Research. vol 14(5): 323-328. doi: https://doi.org/10.1002/10991573(200008)14:5\%3C323::AIDPTR621\%3E3.0.CO;2-Q.

Cho NH, Shaw JE, Karuranga S, Huang Y, da Rocha Fernandes JD, Ohlrogge AW, Malanda B. 2018. IDF Diabetes Atlas: Global estimates of diabetes prevalence for 2017 and projections for 2045. Diabetes Research and Clinical Practice. vol 138: 271-281.

doi: https://doi.org/10.1016/j.diabres.2018.02.023.

Desai SD, Saheb SH, Das KK, Haseena S. 2015. Effect of thymoquinone on MDA and SOD levels in sterptozotocine induced diabetic albino rats. Journal of Pharmaceutical Sciences and Research. vol 7(8): 523-526.

Dhindsa S, Ghanim H, Batra M, Dandona P. 2018. Hypogonadotropic hypogonadism in men with diabesity. Diabetes Care. vol 41(7): 1516-1525. doi: https://doi.org/10.2337/dc17-2510.

Fishman SL, Sonmez H, Basman C, Singh V, Poretsky L. 2018. The role of advanced glycation endproducts in the development of coronary artery disease in patients with and without diabetes mellitus: a review. Molecular Medicine. vol 24(1): 1-12. doi: https://doi.org/10.1186/s10020-0180060-3.

Forouhi NG, Wareham NJ. 2014. Epidemiology of 
diabetes. Medicine (Abingdon). vol 42(12): 698702. https://dx.doi.org/10.1016\%2Fj.mpmed.2014.09.0 07.

Hasan MA, Mustapha NM, Kadir AA, Hezmee M. 2018. Potential role of Nigella sativa (NS) in abating oxidative stress-induced toxicity in rats: a possible protection mechanism. IOSR Journal of Pharmacy and Biological Sciences (IOSR-JPBS). vol 13(5): 29-42. doi: https://doi.org/10.9790/30081305032942.

Laleethambika N, Anila V, Manojkumar C, Muruganandam I, Giridharan B, Ravimanickam T, Balachandar V. 2019. Diabetes and sperm DNA damage: Efficacy of antioxidants. $S N$ Comprehensive Clinical Medicine. vol 1(1): 49-59. doi: https://doi.org/10.1007/s42399-018-0012-9.

Marbat MM, Ali MA, Hadi AM. 2013. The use of Nigella sativa as a single agent in treatment of male infertility. Tikret Journal of Pharmaceutical Sciences. vol 9(1): 19-29.

Matough FA, Budin SB, Hamid ZA, Abdul-Rahman M, Al-Wahaibi N, Mohammed J. 2014. Tocotrienolrich fraction from palm oil prevents oxidative damage in diabetic rats. Sultan Qaboos University Medical Journal. vol 14(1): 95-103. doi: https://doi.org/10.12816/0003342.

Morrison CD, Brannigan RE. 2015. Metabolic syndrome and infertility in men. Best Practice \& Research Clinical Obstetrics \& Gynaecology. vol 29(4): 507 515. doi: https://doi.org/10.1016/j.bpobgyn.2014.10.006.

Omolaoye T, Du Plessis SS. 2018. Diabetes mellitus and male infertility. Asian Pacific Journal of Reproduction. vol 7(1): 6-14. doi: https://doi.org/10.4103/2305-0500.220978.

Parandin R, Yousofvand N, Ghorbani R. 2012. The enhancing effects of alcoholic extract of Nigella sativa seed on fertility potential, plasma gonadotropins and testosterone in male rats. Iranian Journal of Reproductive Medicine. vol 10(4): 355362.

Pourmasumi S, Sabeti P, Rahiminia T, Mangoli E, Tabibnejad N, Talebi AR. 2017. The etiologies of
DNA abnormalities in male infertility: an assessment and review. International Journal of Reproductive BioMedicine. vol 15(6): 331-344.

Qinna NA, Badwan AA. 2015. Impact of streptozotocin on altering normal glucose homeostasis during insulin testing in diabetic rats compared to normoglycemic rats. Drug Design, Development and Therapy. vol 9: 2515-2525. doi: https://doi.org/10.2147/DDDT.S79885.

Ramaswamy S, Weinbauer GF. 2014. Endocrine control of spermatogenesis: Role of FSH and LH/testosterone. Spermatogenesis. vol 4(2): 1-15. doi: https://doi.org/10.1080/21565562.2014.996025.

Réus GZ, Carlessi AS, Silva RH, Ceretta LB, Quevedo J. 2019. Relationship of oxidative stress as a link between diabetes mellitus and major depressive disorder. Oxidative Medicine and Cellular Longevity. $\quad$ vol 2019: 1-6. doi: https://doi.org/10.1155/2019/8637970.

Saeedi P, Petersohn I, Salpea P, Malanda B, Karuranga S, Unwin N, Colagiuri S, Guariguata L, Motala AA, Ogurtsova K, Shaw JE, Bright D, Williams R. 2019. Global and regional diabetes prevalence estimates for 2019 and projections for 2030 and 2045: Results from the International Diabetes Federation Diabetes Atlas. Diabetes Research and Clinical Practice. vol 157: 1-10. doi: https://doi.org/10.1016/j.diabres.2019.107843.

Singh VP, Bali A, Singh N, Jaggi AS. 2014. Advanced glycation end products and diabetic complications. The Korean Journal of Physiology \& Pharmacology. vol 18(1): 1-14. doi: https://doi.org/10.4196/kjpp.2014.18.1.1.

Solomon SD, Chew E, Duh EJ, Sobrin L, Sun JK, VanderBeek BL, Wykoff CC, Gardner TW. 2017. Diabetic retinopathy: a position statement by the American Diabetes Association. Diabetes Care. vol 40(3): 412-418. doi: https://doi.org/10.2337/dc162641.

Walker WH. 2011. Testosterone signaling and the regulation of spermatogenesis. Spermatogenesis. vol 1(2): 116-120. doi: https://doi.org/10.4161/spmg.1.2.16956. 